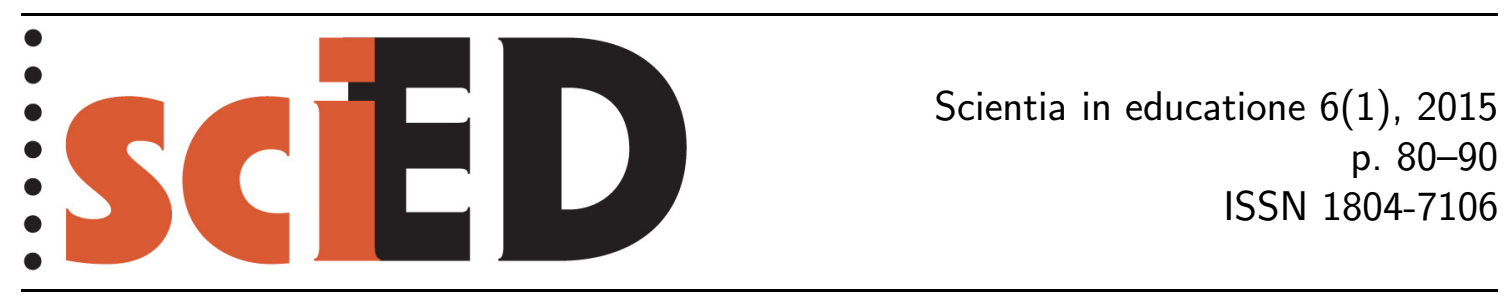

\title{
Didaktické využití školních zahrad v České republice na primárním stupni základních škol
}

\author{
Zbyněk Vácha
}

\begin{abstract}
Abstrakt
Hlavním cílem výzkumu bylo zmapovat aktuální stav využívání školních zahrad ve výuce na primárním stupni základních škol v České republice, determinovat potenciální možnosti začlenění školních zahrad do výuky v budoucnosti, a potvrdit hypotézu, že školní zahrada poskytuje vhodný výukový prostor pro výuku na primárním stupni základních škol a zároveň nabízí dostatek př́ležitostí pro aplikaci badatelsky orientovaných prvků. Na výzkumu participovalo 119 učitelů ze 119 základních škol a 44 studentek Jihočeské univerzity v Ceských Budějovicích studujících obor učitelství pro 1. stupeň základních škol. Data byla získávána dotazníkovým šetřením a analýzou školních vzdělávacích programů. Z výsledku výzkumu vyplývá, že školní zahrady jsou ve výuce na prvním stupni základních škol využívány v rámci všech definovaných vzdělávacích oblastí a jsou postupně transformovány, z čistě pěstitelských, na prostory, které umožňuji učitelům do výuky zařadit praktické aktivity v nejrůznějších disciplínách. Představují tak vhodné prostředí pro aplikaci prvků badatelsky orientovaného vyučování.
\end{abstract}

Klíčová slova: školní zahrada, primární stupeň, badatelsky orientované vyučování.

\section{Didactic Usage of School Gardens at Primary Schools in the Czech Republic}

\begin{abstract}
The main aim of our research was to map the current use of school gardens at primary schools in the Czech Republic, to determinate possible ways of integrating school gardens in teaching in the future and to confirm a hypothesis that school gardens provide suitable space for teaching at primary schools. Moreover, school gardens offer enough opportunities for the application of elements of inquiry based education. Total of 119 teachers from 119 primary schools and 44 students - future elementary teachers, studying at the Faculty of Education, the University of South Bohemia, took part in the research. The data consisted of filled-in questionnaires and of School Education Programmes. The results of our analysis of data show that school gardens are used for teaching at primary schools in all defined educational areas. School gardens are gradually transformed from the floricultural areas only to the areas which allow for integrating practical activities in different school subjects. Thus, school gardens seem to be suitable for the application of inquiry based education.
\end{abstract}

Key words: school garden, primary school, inquiry based teaching. 


\section{VÝUKA V OBLASTI Př́́RODNÍCH VĚD}

V České republice, v Evropě, ale i ve Spojených státech amerických můžeme pozorovat krizi ve výuce př́rodovědných předmětů (Papáček, 2010; Evropská komise, 2007; Klemmer, Waliczek \& Zajicek, 2005; National Research Council, 1996). Düvody ovlivňující aktuální stav výuky přírodovědných předmětů přinášejí např́iklad výsledky výzkumu PISA 2012 (Programme for International Student Assessment); Papáček (2010); McKinsey et al. (2010); společnost White Wolf Consulting (2009) či Škoda a Doulík (2009). Za hlavní důvody krize považují především stagnující zájem studentů o př́rodovědné a technické obory a pokles dosažených výsledků žáků v prostředí základních a středních škol. Tato situace je podle Greena a Griffitha (2003) ovlivněna skutečností, že výuka př́rodovědných předmětů je příliš zaměřena na prosté memorování faktů, postrádá kontextuální souvislosti a interdisciplinární propojení. Čížková (2006) dodává, že v rámci neustálého nárůstu nových poznatků a orientace učiva ve prospěch teoretických poznatků dochází ke zvýšení jeho náročnosti. Bowers (2000) uvádí, že školní systém využívá didaktické přístupy, které minimalizují aktivitu žáků, a naopak pojímá žáka jako pasivního př́jemce informací. Dalším negativním trendem ovlivňujícím vztah žáků $\mathrm{k}$ přírodovědným předmětům je v současném světě výpočetní techniky omezený přímý kontakt dětí s přírodou, který je navíc umocněn v hustě urbanizovaných oblastech (Louv, 2008). Výuka v přírodě má dle Williamse a Browna (2011) potenciál zatraktivnit výuku přírodovědných předmětů a zvýšit zájem o jejich studium. Pro tyto účely představují vhodný prostor areály školních zahrad využitelné již na primárním stupni základních škol (Klemmer, Waliczek \& Zajicek, 2005).

\section{TEORETICKÁ VÝCHODISKA VÝZKUMU}

\section{1 ŠKOLNÍ ZAHRADY}

\subsubsection{VZNIK A VÝVOJ ŠKOLNÍCH ZAHRAD}

Školní zahrady začaly být soustavněji budovány až po vydání Všeobecného školního řádu císařovnou Marií Terezií v roce 1774. Zahrady u škol ale sloužily k potřebám učitelů, kteři si zde pěstovali plodiny pro svou obživu. Za první koncepčně založenou školní zahradu na území současné České republiky je považována zahrada vybudovaná MUDr. Karlem Slavojem Amerlingem v Praze ve 40. letech 19. století (Morkes, 2007). V roce 1869 byl vydán říšský školský zákon, který nařizoval školám mít vlastní zahrady. $\mathrm{K}$ dalšímu rozvoji školních zahrad a $\mathrm{k}$ posílení pracovního vyučování došlo po ukončení 1 . a 2 . světové války. Školní zahrady měly neustále zejména pěstitelské využití. Po roce 1989 naopak došlo v Československu a později v samostatné České republice k výraznému rušení školních zahrad. Důvodů bylo několik: oslabení výuky pracovního vyučování a pěstitelských prací školským systémem, transformace školních zahrad v plochy s odlišným využitím (např. dopravní hřiště, parkoviště, sportovní areály), popřípadě prodej jiným subjektům (Chmelová, 2010). Aktuálně dochází celosvětově k opětovné podpoře využívání školních zahrad ve výuce. Školní zahrady jsou transformovány z čistě pěstitelských na prostory, které umožňují do výuky aplikovat praktické aktivity v rozmanitých disciplínách (Vácha \& Petr, 2013). 


\subsubsection{VYMEZENÍ ŠKOLNÍCH ZAHRAD}

Školní zahrada je mnohými autory (např. Smith \& Motsenbocker, 2005; Robinson \& Zajicek, 2005; Cutter-Mackenzie, 2008) považována za moderní výukový prostor, který umožňuje pedagogům do vyučování začlenit praktické aktivity v rozmanitých mezioborových disciplínách, poskytuje dynamické prostředí, ve kterém se studenti zabývají pozorováním, objevováním, experimentováním a podléhají zde výchovně vzdělávacímu procesu. Prostory školních zahrad představují živou laboratoř, v níž jsou získávány zkušenosti z reálného života názorněji než z př́ikladů v učebnici. Výuka v takovémto prostředí umožňuje učitelům aktivně zapojit žáky do vyučování přímo v přírodě a přiblížit jim tak svět rostlin, živočichů či neživou přírodu (Williams \& Brown, 2012). Právě školní zahrady by mohly představovat ideální místo pro přímý kontakt žáků s př́rodou. Výukou na školní zahradě by se tak učitelé mohli pokusit pomoci najít žákům cestu $\mathrm{k}$ přírodovědným předmětům a př́rodě vůbec (Vácha \& Petr, 2013).

Školní zahrady splňují i další žádoucí trend ve vzdělávání, jsou vhodným prostorem pro rozvoj interdisciplinarity ve výuce. To znamená, že umožňují propojování poznatků z předmětů jako je matematika, přírodověda, výuka jazyků, výtvarná a tělesná výchova či výchova ke zdraví (Sobel, 2004). Školní zahrady také mohou žákům přibližit bezprostřední okolí, ve kterém žijí (Smith, 2002), a představují potenciálně vhodné prostředí pro badatelské činnosti (Smith \& Motsenbocker, 2005; Nabhan, 1997). Poskytují tak příležitost zavádět do výuky rozdílné výukové styly kladoucí větší důraz na aktivitu žáka (Williams \& Brown, 2011). Badatelsky orientované metody výuky využívané $\mathrm{v}$ př́rodě jsou velmi důležitým formativním prvkem žákova vnímání okolního světa, a mohly by tak přispět $\mathrm{k}$ lepším výsledkům žáků ve výuce. Již žáci na primární škole by měli být schopni rozpoznávat jednoduché problémy, navrhovat jejich řešení a realizovat je v praxi, diskutovat o jednotlivých způsobech řešení se spolužáky a s učitelem a využivat jednoduché přístroje k měření, odlišovat př́rodní objekty od umělých prvků, popsat základní životní cykly, organismy a prostředí, ve kterém žijí (Parajuli \& Williams, 2005). Takto zvolené učební postupy pak působí kladně na rozvoj kritického myšlení (Smith \& Gruenwald, 2008). Vzděláváním na školních zahradách navíc mohou učitelé do výuky přinést základní principy udržitelného rozvoje a jiných skutečností využívaných v běžném životě (Castagino, 2005; Kiefer, Wiliams \& Kemple, 1998) a propojovat tak získané znalosti žáků s jejich praktickým využitím (Williams \& Brown, 2011).

\subsection{AKTUÁLNí VYUŽITÍ ŠKOLNÍCH ZAHRAD VE VÝUCE}

V současnosti je využití školních zahrad v České republice, na rozdíl od situace ve Spojených státech amerických, Kanadě, Austrálii, Velké Británii či Německu (Fenoughty, 2001; Seth, 2003; Dyment, 2005; Graham et al., 2005; Parsons, 2006; Cutter-Mackenzie, 2008), ve výuce částečně omezeno, přitom školní zahrady představují vhodné prostředí pro simulaci terénu a areál pro aplikaci terénní výuky v blízkosti budov základních škol (Vácha \& Petr, 2013).

Koncepce školství v České republice „Rámcově vzdělávací program pro základní vzdělávání“ poskytuje učitelům značnou možnost využívat prostory školních zahrad ve vyučovacím procesu, a to nejen ve výuce přírodovědných předmětů (Horká, 1996). 


\section{Cíl vÝZKUMU}

Hlavním cílem výzkumu je zmapovat aktuální stav využívání školních zahrad v České republice ve výuce na primárním stupni základních škol a determinovat potenciální možnosti začlenění školních zahrad do výuky v budoucnosti. Potvrdit tak hypotézu, že školní zahrada, která je ve výchovně vzdělávacím procesu často opomíjená, poskytuje vhodný výukový prostor pro výuku na primárním stupni základních škol a zároveň nabízí dostatek příležitostí pro aplikaci badatelsky orientovaných prvků. Př́spěvek svým zaměřením navazuje na výzkumy Váchy a Petra (2013), pracovníků střediska environmentální výchovy a vzdělávání Chaloupky (Burešová et al., 2007) či na výzkum Grahama et al. (2005) z kalifornského prostředí.

\section{METOdiKa VÝZKUMU A PRIMÁRNí INFORMACE O RESPONDENTECH}

Data byla získávána dotazníkovým šetřením a analýzou školních vzdělávacích programů jednotlivých škol v České republice s ohledem na zařazování aktivit realizovaných nebo realizovatelných na školních zahradách v prostředí 1. stupně základních škol. Dotazníky byly vždy vyplňovány pedagogem vyučujícím na 1. stupni patřičné základní školy během osobního setkání s autorem. Fakt, že výuka v prostředí 1. stupně základních škol je v České republice takřka výhradně doménou žen, ovlivňuje genderové zastoupení dotazovaných (94\% vzorku tvořily ženy). Jednalo se tedy o tzv. dostupný výběr (Skutil, 2011).

Dotazník obsahoval 16 otázek a byl rozdělen do 5 oblastí: a) identifikační údaje, b) obecné informace o školní zahradě, c) využití školních zahrad při výuce (pro výuku v rámci jakých vzdělávacích oblastí a $\mathrm{k}$ jakým výukovým aktivitám je využívána, vhodnost školních zahrad pro aplikaci prvků badatelsky orientovaného vyučování), d) další využití školních zahrad a e) příčiny zániku školních zahrad. Dále měli dotazovaní vlastními slovy napsat, jak vnímají prostory školních zahrad. Výzkumný nástroj byl vytvořen modifikací dotazníků střediska environmentální výchovy a vzdělávání Chaloupky (Burešová et al., 2007) a Grahama et al. (2005) pro výzkum ve státě Kalifornia tak, aby odpovídal aktuálnímu výzkumného záměru (došlo k zeštíhlení původních výzkumných nástrojů a naopak byly přidány dotazníkové položky týkající se výuky badatelsky orientovaného vyučování v prostorách školních zahrad). Dotazník byl pilotně testován dvaceti náhodně vybranými pedagogy 1. stupně základních škol a následně upraven do definitivní podoby. Sběr dat probíhal od září 2013 do června 2014. Osobním přístupem k jednotlivým vyučujícím byla zajištěna $100 \%$ návratnost vyplněných dotazníků. Na průzkumu spolupracovalo 119 učitelů ze 119 různých základních škol z celé České republiky. Vzorek obsahoval jednak učitele začátečníky (první rok v praxi) a na druhé straně pedagogy s mnohaletou praxí (max. uvedená doba praxe byla 40 let). Průměrná doba praxe respondentů činila $13,5 \mathrm{roku}$.

Na výzkumu dále participovalo 44 studentek (genderové zastoupení je dáno oborem, který je takřka výhradně doménou žen) Jihočeské univerzity v Českých Budějovicích studujících obor učitelství pro první stupeň základních škol (2. ročník). Do výzkumu byly zařazeny záměrně, aby mohlo dojít k porovnání názorů na výuku v prostředí školních zahrad mezi pedagogy z praxe a budoucími vykonavateli pedagogického řemesla v rámci prvního stupně základních škol. Úkolem každé participující bylo během jedné vyučovací hodiny na prázdný papír spontánně uvést libovolný po- 
čet tematických okruhů či aktivit z různých vzdělávacích oblastí, pro jejichž výuku by bylo vhodné využít prostředí školní zahrady, napsat, zdali vůbec školní zahradu považují jako vhodný výukový prostor či nikoliv, a vyjádřit svůj názor na využití badatelsky orientovaných metod ve výuce v prostředí školních zahrad na prvním stupni základních škol. Administrace odpovědí pak spočívala v jejich zaznamenání, generalizaci a přiřazení do příslušné vzdělávací oblasti.

\section{VÝSLEDKY}

\subsection{VYUŽITÍ ŠKOLNÍCH ZAHRAD V PROSTŘEDí 1. STUPNĚ ZÁKLADNÍCH ŠKOL}

Možnost využívat školní zahradu pro výukové a ostatní aktivity má ze 119 participujících školských zařízení 86 základních škol (72\% dotazovaných). Zbylých 33 škol (28\% dotazovaných) školní zahradou nedisponuje. Školní zahrady jsou u většiny škol přímo součástí areálu školy. 79 učitelů (66 \%) považuje školní zahradu za ideální prostor pro doplnění a obohacení konvenční výuky na prvním stupni základních škol. 22 dotazovaných (19 \%) ve školních zahradách nevidí žádoucí potenciál pro výuku na primární škole a 18 respondentů $(15 \%)$ si není po zvážení výhod a nevýhod implementace školních zahrad do výuky jisto.

Nejčastěji mají zahrady u škol rozlohu v rozmezí od $100 \mathrm{~m}^{2}$ do $500 \mathrm{~m}^{2}$. Vyskytují se však i zahrady, které svou rozlohou převyšují $1000 \mathrm{~m}^{2}$. Druhým extrémem jsou pak školní zahrady menší než $100 \mathrm{~m}^{2}$ (viz obr. 1).

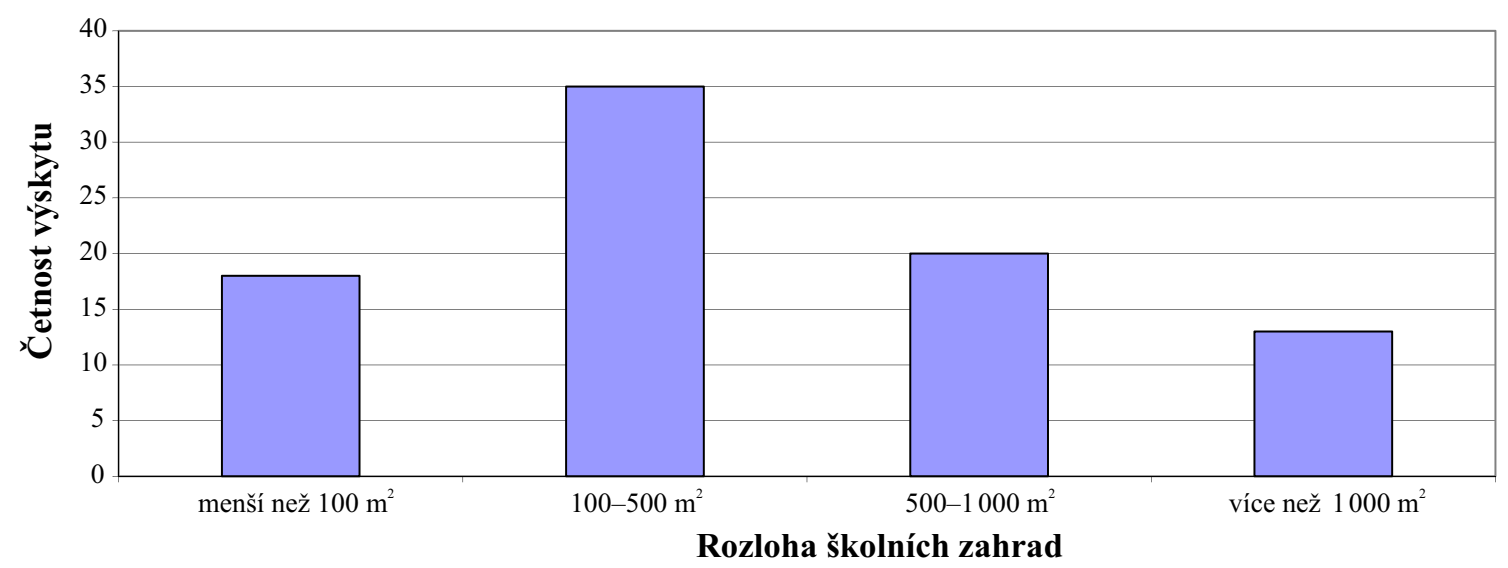

Obr. 1: Přibližná rozloha školních zahrad

Z 33 škol, které nemají možnost využívat školní zahradu, ji 12 škol v minulosti mělo, ale došlo k jejímu zrušení či přeměně na plochy s odlišným využitím (např. parkoviště, školní hřiště, prodej pozemku jinému subjektu). Základní školy, které nemají k dispozici využití školní zahrady, o jejich vybudování prozatím neuvažují. Jako hlavní důvody jsou uváděny absence potřebné plochy pro vybudování školní zahrady, vysoké finanční náklady na vývoj a údržbu, malé pochopení ředitelů škol a nedostatečná opora pro výuku na školních zahradách v kurikulárních dokumentech. Ze slovních odpovědí učitelů na otevřenou dotazníkovou položku Jak vnímají učitelé školní zahrady? vyplývá, že učitelé vidí školní zahrady jako prostor, který jim umožňuje dostat děti do přírody v relativně krátkém časovém úseku, a seznámit je tak především s prř́rodními podmínkami v bezprostředním okolí školy a mnohdy i v okolí bydliště žáků. 
Tabulka 1 poukazuje na skutečnost, že školní zahrady jsou v České republice stále vybaveny převážně prvky typickými pro výuku pěstitelských prací. Postupně však dochází $\mathrm{k}$ jejich přeměně či dostavbě v zahrady s komplexnějším využitím, především díky budování interdisciplinárních prvků, jako jsou broukoviště, vodní biotopy, meteorologické stanice atd.

Tab. 1: Vybavení školních zahrad

\begin{tabular}{lr}
\hline oddělení okrasných rostlin & 48 \\
\hline zelinářské oddělení & 39 \\
\hline Ovocný sad & 36 \\
\hline skleník & 30 \\
\hline př́rodní učebna & 26 \\
\hline oddělení léčivých rostlin & 22 \\
\hline biotop suché stanoviště & 14 \\
\hline broukoviště & 13 \\
\hline vodní biotop & 10 \\
\hline meteorologická stanice & 10 \\
\hline geologická stezka & 6 \\
\hline hřiště & 5 \\
\hline hmatový chodník & 5 \\
\hline ptačí a netopýří budky & 4 \\
\hline
\end{tabular}

\subsection{VÝUKA NA ŠKOLNÍ ZAHRADĚ V RÁMCI JEDNOTLIVÝCH VZDĚLÁVACÍCH OBLASTÍ NA PRVNÍM STUPNI ZÁKLADNÍCH ŠKOL}

V České republice je pro výuku na prvním stupni základních škol definováno celkem 7 vzdělávacích oblastí: a) jazyk a jazyková komunikace, b) matematika a její aplikace, c) informační a komunikační technologie, d) člověk a jeho svět, e) člověk a zdraví, f) umění a kultura a g) člověk a svět práce. Všechny školy, které disponují školní zahradou a participují na výzkumu, ji využívají k výuce alespoň v jedné vzdělávací oblasti (viz obr. 2).

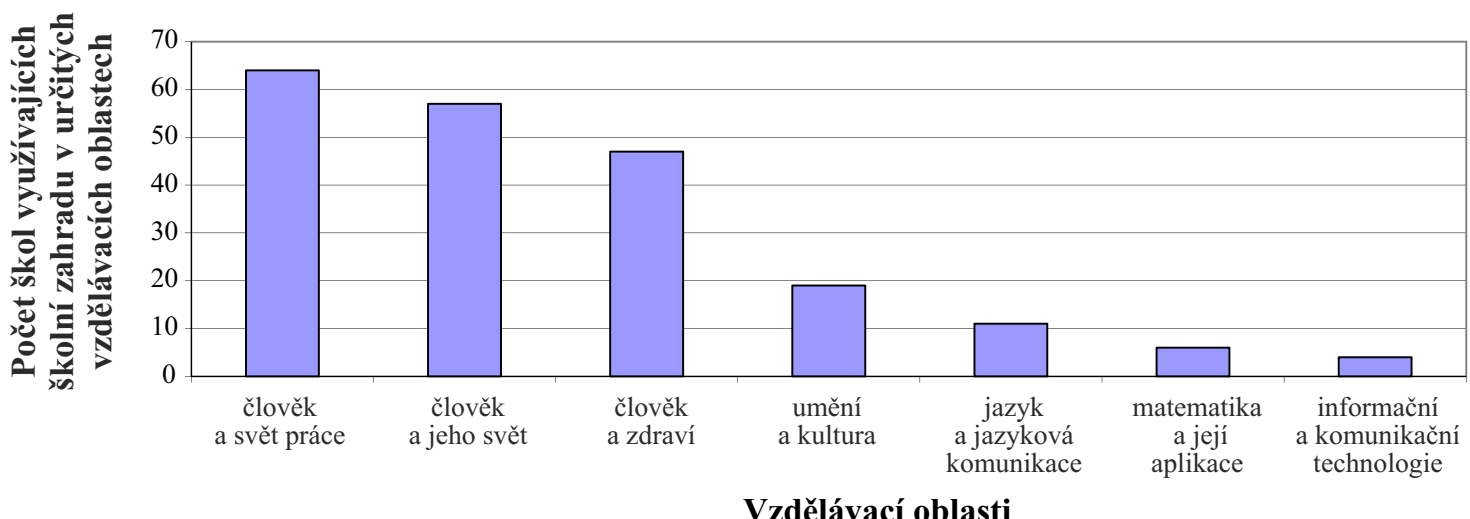

Obr. 2: Využití školní zahrady v jednotlivých vzdělávacích oblastech na 1. stupni ZŠ

Jako příklady konkrétních aktivit pro výuku na školní zahradě spadajících do příslušných vzdělávacích oblastí pro první stupeň, uváděných dotazovanými učiteli, můžeme uvést následující: a) člověk a svět práce - výroba hmyzího hotelu, krmítka, 
ptačích či netopýřích budek, výsadba a sklizeň plodin, b) člověk a jeho svět - inventarizační výzkum a pozorování různých stanovište, determinace organismů, vliv teploty na výskyt živočichů, pozorování proměn přírodnin v závislosti na ročním období, faktory potřebné pro růst a vývoj rostlin, zkoumání potravních řetězců, meteorologické prvky, c) pěstování bylin a jejich následné využití (např. výroba bylinkového čaje), zdravá výživa a správné stravovací návyky, nejrůznější pohybové aktivity na čerstvém vzduchu, d) umění a kultura - frotáž kưry stromů, výroba ručního papíru, kresba a malba zahradních objektů, e) jazyk a jazyková komunikace - popsat den ústy rostliny $\mathrm{v}$ zahradě, opatření rostlin tabulkami se jmény, čtení o zahradě, vedení zahradního deníku, f) matematika a její aplikace - počítání zástupců jednotlivých přírodnin, vytyčení délkových měr, jednoduché grafy teplot půdy a vzduchu, odečítání dat z meteorologické stanice a g) informační a komunikační technologie pořizování a jednoduché počítačové zpracování fotografíi zahradních objektů.

Téměř polovina základních škol má pro výuku na školní zahradě v učebních osnovách dokonce zakotvenou pevnou časovou dotaci. Jedná se o 55 z dotazovaných škol (46\%). Tato časová dotace je variabilní. Obecně lze říci, že stoupá společně s ročníkem školní docházky. To znamená, že nejmenší časovou dotaci pro výuku na školní zahradě mají žáci v 1. ročníku, a naopak nejvyšší pak v 5. ročníku. Ostatní školy, které vlastní školní zahradu, ji využívají dle potřeby a zejména v závislosti na vyučovaném tématu, pro projektové dny či jako zásobárnu experimentálního materiálu. Většina participujících navíc ve školních zahradách vidí vhodné prostředí pro zavádění badatelsky orientovaných prvků do vyučování (91 respondentů, 76 \%) a to zejména ve vzdělávací oblasti člověk a jeho svět (např. pro tematické celky jako: skladba rostlinného těla, složení půdy či objevování a determinace obyvatelů školní zahrady).

Školní zahrady však nejsou využívány jen $\mathrm{k}$ účelům vázaným přímo $\mathrm{k}$ výuce samotné. Často jsou využívány i pro mimo výukové aktivity, např. pro pohyb žáků na čerstvém vzduchu o přestávkách či v rámci školní družiny, a i přes všechny hygienické předpisy jako zdroj čerstvého ovoce a zeleniny ve školní jídelně.

Výzkumu se účastnily také studentky učitelství pro první stupeň základních škol (viz metodika). Dvacet respondentek $(45 \%)$ z řad studentek by školní zahradu vůbec do vyučování nezahrnulo, 15 dotazovaných $(35 \%)$ naopak vidí ve výuce na školních zahradách přínos pro žáky na primární škole a do vyučování by se ji snažilo co nejvíce implikovat a 9 dotazovaných $(20 \%)$ by se rozhodlo až na základě konkrétní podoby a polohy školní zahrady. Jako hlavní důvod, proč nevyužívat školní zahrady ve výuce, respondentky uváděly především neoblibu pěstitelských prací během základní školní docházky, mezi dalšími odpověd’mi se objevila přílišná časová náročnost, nedostatečné materiální zabezpečení školních zahrad či absence tematicky zaměřeného předmětu v pregraduální přípravě. Obrázek 3 zachycuje rozřazené četnosti aktivit pro výuku na školní zahradě do příslušných vzdělávacích oblastí tak, jak je respondentky uvedly.

Pro upřesnění můžeme uvést příklady konkrétních návrhů aktivit vhodných pro výuku na školní zahradě tak, jak je vidí budoucí učitelky pro primární stupeň základních škol: a) člověk a jeho svět - porovnávání různých biotopů (zahradní jezírko, květnatá louka, písčina, ... ), pozorování oblohy, určení světových stran, tvorba senného nálevu, geocashing, odlitky stop či určování stáří stromů, b) člověk a svět práce - výroba ptačích budek, větrníků, základní agrární postupy, tvorba kompostéru a založení kompostu, výroba vánočních svícnů, pletení velikonočních pomlázek či zazimování školní zahrady, c) umění a kultura - kreslení a malba zahradních objektů, barvení pomocí přírodních materiálů, výroba pravěkých nástrojů či posta- 


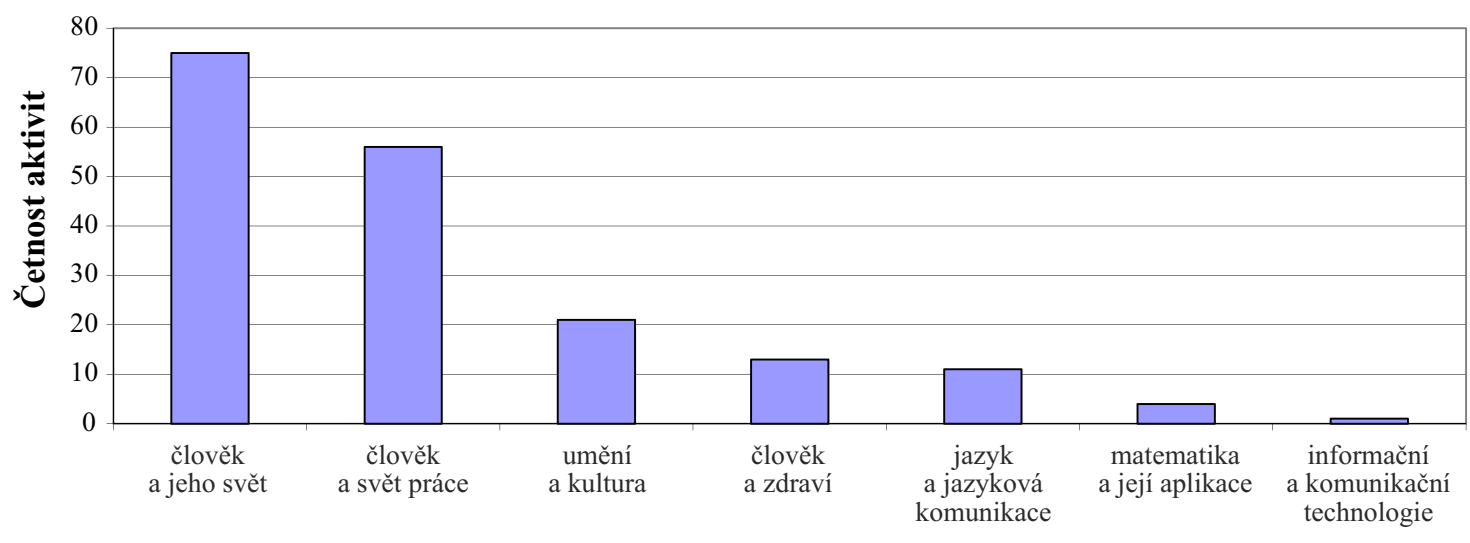

Vzdělávací oblasti

Obr. 3: Aktivity pro výuku na školní zahradě v rámci jednotlivých vzdělávacích oblastí pohledem studentek učitelství pro první stupeň základních škol

viček z kaštanů, d) člověk a zdraví - založení bylinkové spirály, výroba jednoduchých mastiček, pohyb po pocitovém chodníčku, seznámení se základy první pomoci či různá relaxační cvičení, e) jazyk a jazyková komunikace - vyprávění pohádky o zahradě, popis zahrady, výuka slovní zásoby cizího jazyka či učení pojmenovávat věci správným jménem, f) matematika a její aplikace - výuka elementárních početních operací s využitím objektů na školní zahradě a g) informační a komunikační technologie - základní zpracování fotografií pořízených na školní zahradě. Celkem 31 respondentek $(70 \%)$ vidí v prostorách školních zahrad potenciálně vhodné prostředí pro aplikaci metod badatelsky orientovaného vyučování, zejména z hlediska dostatečné zásobárny experimentálního materiálu, zbylých $13(30 \%)$ je opačného názoru.

\section{Diskuse A ZÁVĚR}

Při celkovém pohledu na výsledky aktuálního výzkumu můžeme konstatovat, že pomalu dochází ke změně názoru pedagogické veřejnosti na využití školních zahrad ve výukovém prostředí prvního stupně základních škol. Školní zahrady, jak už uvádí např. Vácha a Petr (2013) či Burešová et al. (2007), jsou v České republice využívány v rámci všech existujících vzdělávacích oblastí. Na rozdíl od situace ve Spojených státech amerických, v Kanadě či Velké Británii jsou školní zahrady ovšem nejvíce využívány ve vzdělávací oblasti člověk a svět práce. Američtí učitelé, jak vyplývá z výzkumu Grahama et al. (2005), využívají školní zahrady zejména pro výuku v oblasti přírodovědných předmětů (95 \% zúčastněných škol, $N=4194$ škol), environmentálních studií (70 \%), zdravé výživy (66 \%), jazyků (60\%) a matematiky (60 \%). Pracovní činnosti, které bychom v České republice mohli považovat za ekvivalent vzdělávací oblasti člověk a svět práce, se z hlediska četnosti odpovědí respondentů objevily až na následujícím místě (pro výuku pracovních činností využivá školní zahrady pouze $46 \%$ na výzkumu participujících škol). Zde můžeme sledovat hlavní rozdíl mezi využiváním školní zahrady v České republice a ve státech, jako jsou Spojené státy americké, Kanada či Velká Británie, jelikož k podobným závěrům jako Graham et al. (2005) docházejí výzkumní pracovníci v Kanadě, Německu a Velké Británii (napřr. Seth, 2003; Dyment, 2005; Parsons, 2006; Cutter-Mackenzie, 2008). V České republice na tento trend, měnit školní zahrady z čistě pěstitelských na prostory, které umožňují do výuky začlenit praktické aktivity v rozmanitých mezi- 
oborových disciplínách, pomalu navazujeme. Postupně dochází v prostředí školních zahrad k oslabení výuky v rámci vzdělávací oblasti člověk a svět práce na úkor ostatních vzdělávacích oblastí, zejména pak oblastí jako člověk a jeho svět, umění a kultura a člověk a zdraví, které zaznamenaly za posledních deset let ve vzdělávání v prostředí školních zahrad viditelný nárůst (Vácha \& Petr, 2013). Tato skutečnost je podpořena zaváděním nových prvků do prostředí školních zahrad (např. hmyzí hotel, broukoviště, geologická stezka, biotop zahradní jezírko, biotop písčina, květnatá louka, hřiště, hmatový chodník atd.), které tak umožňují snadnější využití těchto prostor v ostatních vzdělávacích oblastech. Až budoucnost ukáže, zdali transformace výuky v prostředí školních zahrad bude hodnocena jako pozitivní, či se budeme navracet zpět k posílení výuky ve vzdělávací oblasti člověk a svět práce. Určitě by ale do budoucna nemělo dojít k úplnému potlačení výuky pěstitelských prací, jak uvádí např. i Burešová et al. (2007).

Rozdílný názor na využívání školních zahrad můžeme nalézt v názorech učitelů z praxe a studentek 2. ročníku učitelství pro první stupeň základních škol. Zatímco většina učitelů (66 \% dotazovaných) z praxe vidí ve školních zahradách ideální prostor pro doplnění a obohacení konvenční výuky na prvním stupni základních škol, téměř polovina respondentek z řad studentek učitelství pro první stupeň základních škol $(44 \%)$ by školní zahradu do výuky vůbec nezařadila. Zde se odráží skutečnost, kdy studentky mají ještě v paměti vlastní zkušenost $\mathrm{s}$ výukou na školní zahradě, která byla v minulosti orientována takřka výhradně na činnosti spadající do oblasti člověk a svět práce a která všeobecně nepatři mezi oblíbené. Na druhé straně vymyslet aktivity pro výuku na školní zahradě nebyl pro studentky žádný problém (viz kapitola Výsledky). To znamená, že tvưrčí potenciál pro výuku na školní zahradě v sobě mají. Úkolem současných pedagogů a pedagožek je pak pomoci budoucím učitelům a učitelkám tento existující potenciál aplikovat do praxe, at již prostřednictvím výuky předmětu pěstitelské práce $\mathrm{v}$ rámci studia na vysoké škole nebo prostřednictvím průběžných pedagogických praxí či organizací speciálně zaměřených seminářů a workshopů. Respondenti z řad učitelů z praxe, ale i studentky učitelství pro první stupeň, spatřují ve školních zahradách potenciálně ideální prostředí pro zavádění aktivizačních metod výuky, jako je např. badatelsky orientované vyučování.

Závěrem můžeme konstatovat, že školní zahrady, jak vyplývá z aktuálního výzkumu, jsou na prvním stupni základních škol využívány ve výuce všech vzdělávacích oblastí, ale i v aktivitách, které s výukou přímo nesouvisejí a mají potenciál pro aplikaci prvků badatelsky orientovaného vyučování. Do budoucna, když zohledníme zlepšující se materiální vybavení nebo postupnou změnu názoru na využití školní zahrady, mají školní zahrady ještě daleko větší potenciál pro častější zapojení do běžné výuky. Mohou tak v budoucnu poskytnout více př́ležitostí aktivně zapojit žáky do vyučování prrímo $\mathrm{v}$ př́rodě a podporovat jejich vztah $\mathrm{k}$ přírodovědným předmětům a prŕrodě vůbec.

\section{PODĚKOVÁNí}

Studie vznikla s grantovou podporou Grantové agentury Jihočeské univerzity GAJU 078/2013/S. 


\section{LITERATURA}

Bowers, C. A. (2000). Let them eat data: How computers affect education, cultural diversity, and the prospects of ecological sustainability. Athens: University of Georgia Press.

Burešová et al. (2007). Učíme se v zahradě. Kněžice: Středisko environmentální a ekologické výchovy Chaloupky.

Castagnino, L. (2005). Gardens and grade level expectations: The link between environmental education and standardized assessments. [Unpublished masterZ̆s thesis]. Providence, RI: Brown University.

Cutter-Mackenzie, A. (2008). Research Report 2: Multicultural school gardens. Melbourne: Monash University and Gould Group.

Č́žková, V. (2006). Experimentální metoda v oborových didaktikách - možnosti a omezení. Příspěvek na konferenci Současné metodologické př́istupy a strategie pedagogického výzkumu pořádané ve dnech 5.-7. záŕí 2006 na ZČU [cit. 2014-10-05] Dostupné z http://www.kpg.zcu.cz/capv/HTML/127/default.htm

Dyment, J. E. (2005). The Power and Potential of School Ground Greening in the Toronto District School Board. Toronto: Evergreen.

Evropská komise. (2007). Science Education NOW. Dostupné z http://ec.europa.eu/research/science-society/document_library/pdf_06/report-rocard-onscience-education_en.pdf

Fenoughty, S. (2001). The Landscape of the School Grounds. Environmental education Research, 68, 6-8.

Graham, H., Beall, D. L., Lussier, M., Mclaughlin, P. \& Zidenberg-Cherr, S. (2005). Use of School Gardens in Academic Instruction. Journal of Nutrition Education and Behavior, 37(3), 147-151.

Greene, M. \& Griffith, M. (2003). Feminism, philosophy, and education: Imagining public spaces. In Blake, N., Smeyers, P., Smith, R. \& Standish, P. (Eds.), The Blackwell guide to the philosophy of education (73-92). Oxford: Blackwell.

Horká, H. (1996). Teorie a metodika ekologické výchovy. Brno: Paido.

Chmelová, Š. (2010). Pěstitelství na základni škole I. Didaktika výuky. Ceské Budějovice: Jihočeská univerzita v Českých Budějovicích.

Kiefer, J., Wiliams, D. R. \& Kemple, M. (1998). Digging deeper: Integrating youth gardens into schools $\&$ communities. Vermont: Foof Works.

Klemmer, C. D, Waliczek, T. M. \& Zajicek, J. M. (2005). Growing minds: the effects of a school gardening program on the science achievement of elementary students. Hort technology, 15(3) 448-452.

Louv, R. (2008). Last child in the woods: Saving our children from nature-deficit disorder. Chapel Hill, NC: Algonquin Books.

McKinsey et al. (2010). Klesající výsledky českého a základního školství: fakta a řešení. Dostupné z http://www.arg.cz/Ok_koncepce/Edu_report.pdf

Morkes, F. (2007). Učíme se v zahradě. Kněžice: Stř̌edisko environmentální a ekologické výchovy Chaloupky.

Nabhan, G. P. (1997). Cultures of habitat: on nature, culture, and story. Washington, DC: Counterpoint. 
National Research Council. (1996). National Science Education Standards. Washington, DC: The National Academy Press.

Papáček, M. (2010). Limity a šance badatelsky orientovaného vyučování přírodopisu a biologie v České republice, In M. Papáček (Ed.), Didaktika biologie v České republice 2010 a badatelsky orientované vyučování. DiBi 2010. Sborník př́spěvků semináře, 25. a 26. března 2010 (145-162). České Budějovice: Jihočeská univerzita v Českých Budějovicích.

Parajuli, P. \& Williams, D. (2005). Learning Gardens Laboratory: Health, multiculturalism, and avademic achievement. A report submitted to the Portland City Council, Portland, Oregon.

Parsons, G. (2006). Heading Out. Exploring the impact of outdoor experiences on young children. Kent: Learning through Landscapes.

PISA. (2012). Program for international Students Assessment. Dostupné z http://www.pisa2012.cz/

Robinson, C. W. \& Zajicek, J. M. (2005). Growing minds: the effects of a one-year school garden program on six constructs of life skills of elementary school children. Hort Technology, 15(3), 453-457.

Seth, A. (2003). The history of school garden in Germany. Environmental Education, 73, $9-10$.

Skutil, M. (2011). Základy pedagogicko-psychologického výzkumu pro studenty učitelství. Praha: Portál.

Smith, G. A. (2002). Place based education: learning to be where we are. Phi Delta Kappan, 82(8), 584-594.

Smith, G. \& Gruenevald, D. (2008). Place-based education in the global age: Local diversity. New York, NY: Lawrence Erlbaum Associates.

Smith, L. L. \& Motsenbocker, C. E. (2005). Impact of hands-on science through school gardening in Louisiana public elementary schools. HortTechnology, 15(3), 439-443.

Sobel, D. (2004). Place-based education: Connecting classrooms and communities. Great Barrington, MA: The Orion Society.

Škoda, J. \& Doulík, P. (2009). Vývoj paradigmat přrírodovědného vzdělávání.

Pedagogická orientace, 19(3), 24-44.

Vácha, Z. \& Petr, J. (2013). Inquiry based education at primary school throught school gardens. Journal of International Scientific Publications: Education Alternatives, 4, 219-230.

White Wolf Consulting, (2009). Důvody nezájmu žáků o př́rodovědné a technické obory. Dostupné z http://ipn.msmt.cz/data/uploads/portal/Duvody nezajmu zaku o PTO.pdf

Williams, D. R. \& Brown, J. D. (2011). Living soil and sustainability education: linking pedagogy with pedology. Journal of Sustainability Education, vol. 2. Dostupné z http://www.jsedimensions.org/wordpress/wp-content/uploads/2011/03/

WilliamsBrown2011.pdf

ZBYNĚK VÁCHA, zvacha@pf.jcu.cz

Jihočeská univerzita, Pedagogická fakulta

Katedra biologie

Jeronýmova 10, 37005 České Budějovice, Česká republika 